given in the "Berliner Klinische Wo(henschrift," 18 )2, $\mathrm{X}_{0}$. 30 , is referred to in this Journal. Swelling of the natsal mucous membrane is often caused by mouth-breathing. By application of Feldbausch's nasal dilator, such swellings, often only produced by heromia, are cured without any other medication. The mastoid cell, are often diseased, discoloured, and filled with mucus or purulent contents. The antrum of Highmore and mastoid cells are more often diseased in children than in adults, so that in these cases a propagation of the nasal and aural diseases seems probable. The author belieres that by the ustral methods of blow ing the nose infertious material can enter the mucous membrane of the accessory caritics, and produce infections here. In the same manner, l'olitzer's air douche and, though not to so high a degree, catheterism may conduct infectious material to the accessory cavities. The author, therefore, prefors in cases of perforation of the membrana tympanito apply Siesle's pneumatic ear speculum to remove the pus. The author helicies that the furamina accessoria of the nasal wall of the upper jaw are sceondary formation, and are formed when the natural hole is obstructed by hypertrophic mucous membrane. Protrusion of the wall itself the atuhor only saw when there were tumours : never in cases of fluid in the sinus. Fesetations in the nose and adenoid vegetations of the pharynx vault are caused by irritation, and very often by suppuration of the accessory catities. Relation to carious teeth can only be found in few cases of empyemata of the antrum of Highmore. The second part of the book containi the notes of the most interesting of the author's four liundred examinations.

Michatel.

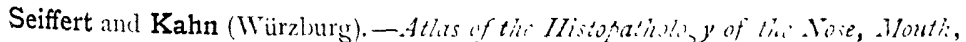

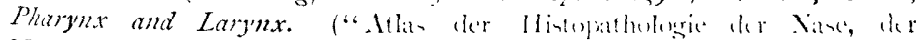
Mundrachenhohle und de Kehllopte." cimtaining it figmes and fo

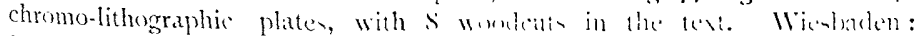
Bergmann, 1 95.

Xot all who are specialists in nasal and laryngeal worl have the time and the ability to conduct exact pathologrico-anatomical researches. To thene such a work will be welcome, in which may be found the histolosy of all those diseases which he mects with in practice. for thone who themselves make histological examinations the illustrations will give much pleasure, from their elegant and cxart reproduction, and the careful selection of the individual specimens. levinning with figures of the nomal nasal mucous membrane, the author follow the varoun forms of intlammation of the nose, and oziena tablen 2-(). Tables j-10are dediciated to the different forms of fibroma ademato-um u-mally called mu our polypi.

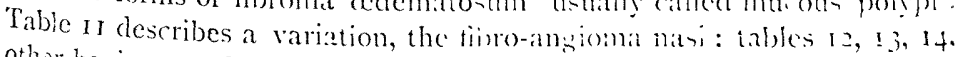
other benign neoplasms of the nowe : tathe 15 . tuberculesin: tablen $10-20$, malignant neoplasms. of these talle wo in of - per i.l interent, figuring the specimens of melano-sarcoma only oberved forir times bhe specimen is from the reviewer's case. Table 2 a deals with the hypertrophic pharen. sheal tonsil, and a very rare case of teratoma pharyllyis: the specimen show's epidermis, corium, tela subcutinc 1 , and hair of the so-called hairy polypi. Tables 22 and 23 show hejertrophied palates and lingtuil tonsils. Taide $2+$ contains a perulo-papilloma of the tomue and a. 
adenoid polypus of the soft palate; table 25 , benign neoplasms of the soft palate; table 26 , granular pharyngitis and leptothrix buccalis; table 27 , an angioma cavernosum of the tongue; table 28 , specimens of macroglossia and of rhinoscleroma, the latter specially instructive because of the localization of the bacilli on the tissue, which is very clear. Table 29 shows tuberculosis of the pharynx ; table 30 , an instructive case of leucoplakia buccalis and a cancer of the tongue; table $3 I$, a sarcoma of the tongue and a lympho-sarcoma of the tonsil. On tables $32-3+$ we find very fine reproductions of benign neoplasms of the larynx; table 35 gives clear pictures of pachydermia and of tuberculosis ; tables $3^{6}$ and 37 treat of cancer and sarcoma of the larynx; table 38 is dedicated to lepra (here also, as in the specimen of rhinoscleroma, a specimen is selected which shows the distribution of the bacilli in the tissuc around the cells in a very clear manner). Table 39 contains a case of laryngeal syphilis, and gives a copy of the normal mucous membrane of the trachea. Table 40 concludes the work with two rery rare neoplasms of the trachea-a papilloma (Seigert's case) and an osteoma (Dennig's case).

The text explains the illustrations in a very clear and concise manner.

Both from a scientific and artistic point of view it is an excellent work of the first rank. The publisher has clone his best to support the authors by most excellent work and faultless execution of the figures, and selection of the best paper.

Hichacl.

\title{
OIL-COLOUR PAINTINGS OF MORBID APPEARANCES IN THE NOSE AND THROAT.
}

\author{
By Dr. Hexig (Berlin).
}

A series of large paintings in oil, representing more or less typical cases of disease of the nose, pharynx, and larynx, by Dr. Hennig (Berlin), was recently exhibited before the Laryngological Society of London by the President. The paintings possessed very considerable artistic merit, and the whole work did the greatest credit to the enthusiasm and industry of the painter. Criticisms and suggestions were specially requested, and, it is needless to say, these were freely offered. The absence of certain typical pictures, common in tuberculosis of the larynx, was commented on, and other less important omissions were pointed out as calling for correction.

It is understood that Dr. Hennig is anxious to make the series as complete as possible for educational purposes, regardless of the time and trouble involved. When this end is attained, he hopes to find a sufficient number of subscriptions to cover the cost of reproduction by chromo-lithography. This would hardly appeal to individual workers, but we would strongly recommend the accuisition of the work by every institution where laryngology and rhinology are taught. To allow this scheme to lapse would be to lose an important aid to the advance of these sciences. The paintings, as they at present stand, have been on view in the rooms of the Royal Medical aud Chirurgical Society in Fianover Square. 